\title{
STUDI KARAKTERISTIK FASILITAS PARKIR DI KANTOR BALAIKOTA SURAKARTA
}

\author{
Dewi Handayani 1)Amirotul MHM 2), Hananta Aji Pramudya 3) \\ 1) Mahasiswa Fakultas Teknik, Prodi Teknik Sipil, Universitas Sebelas Maret \\ 2) Pengajar Fakultas Teknik, Prodi Teknik Sipil, Universitas Sebelas Maret \\ 3) Pengajar Fakultas Teknik, Prodi Teknik Sipil, Universitas Sebelas Maret \\ Jl. Ir. Sutami 36A, Surakarta 57126; Telp. 0271-634524. Email: aiipramudya61@yahoo.co.id
}

\begin{abstract}
The amount of parking space that is not proportional to the volume of vehicles in the Surakarta City Hall office will dismpt the orderliness and comfort of parking users in the Surakarta City Hall Office. For this reason, this study aims to find out the data on the number of parking spaces, obtain parking usage characteristics and recommend management of parking spaces in Surakarta City Hall. The existence of this evaluation is expected to provide an alternative solution to the problem of parking problems in the Surakarta City Hall Office area.

This research was conducted in two stages. The first phase of research on Tuesday is measuring the parking area (inventory of parking spaces) in the Surakarta City Hall Office area. The survey method was carried out by the method of inventorying parking spaces and parking space requirements, surveying parking space requirements was carried out in two ways, namely patrol and cordon surveys. The second phase of the research is to calculate the parking space requirements to obtain the characteristics of the vehicle entering the parking area. This research was conducted on Wednesday and Thursday. Furthermore, the results of the inventory of parking spaces and the parking characteristics data are evaluated to determine the parking area requirements and the number of vehicles using the Surakarta City Hall Office parking lot.

The results showed that the results of the inventory survey were 755 SRP motorycles and 190 SRP cars, maximum parking accumulation for 798 motorbike vehicles, 289 vehicle cars, 2550 vehicles / day motorcycle parking and 644 vehicles / day cars, parking duration the motorbike averages 1.56 hours while the car is 2.57 hours, the parking turnover rate for motorbikes is 3.38 vehicles. The car layout is 3.38 vehicles. / Plots, the maximum parking index for motorbikes is 105.70\%, occurred at 10.30 10.45 WIB and cars totaling 15.11\% occurred at 15.45 - 16.00 WIB. Drivers who use parking space for less than 5 minutes or to deliver as many as 260 vehicles. For this reason, the Surakarta City Hall Office parking space even though the number of available SRPs has greater parking accumulation, the reality in the parking space field is relatively sufficient, because there are still many vehicles that enter to deliver (do not do parking). So that the parking arrangement is recommended with the addition of officers who supervise the parking lot so that the parking lot is neatly arranged without any car parked carelessly which can hamper the circulation of other vehicles, especially on motorycle parking.
\end{abstract}

Keywords: Parking Room Unit (SRP), Office, Parking Inventory, Parking Space Requirement

\begin{abstract}
Abstrak
Luas lahan parkir yang tidak sebanding dengan jumlah volume kendaraan yang ada di dalam kawasan kantor Balaikota Surakarta akan mengganggu ketertiban dan kenyamanan para pengguna parkir yang berada di Kantor Balaikota Surakarta. Untuk itu penelitian ini bertujuan untuk mengetahui data jumlah ruang parkir, medapatkan karakteristik penggunaan parkir dan merekomendasikan manajemen pengaturan ruang parkir di Balaikota Surakarta.Adanya evaluasi ini diharapkan memberikan suatu alternative pemecahan masalah terhadap permasalahan parkir di wilayah Kantor Balaikota Surakarta.

Penelitian ini dilakukan melalui dua tahap.Penelitian tahap pertama pada Hari Selasaberupa pengukuran lahan parkir (inventarisasi ruang parkir) yang terdapat di wilayah Kantor Balaikota Surakarta. Metode survai dilakukan dengan metode inventarisasi ruang parkir dan kebutuhan ruang parkir, survai kebutuhan ruang parkir dilakukan dengan dua cara yaitu survai patrol dan kordon. Penelitian tahap ke dua berupa menghitung kebutuhan ruang parkir untuk memperoleh karakteristik kendaraan yang memasuki area parkiran.Penelitian ini dilakukan pada Hari Rabu dan Kamis. Selanjutnya, data hasil inventarisasi ruang parkir dan data hasil karakteristik parkir di evaluasi untuk mengetahui kebutuhan luas lahan parkir dan jumlah kendaraan yang menggunakan lahan parkir Kantor Balaikota Surakarta.

Hasil penelitian menunjukan bahwa, hasil pelaksanaan survei inventarisasi didapatkan 755 SRP sepeda motor dan 190 SRP mobil, akumulasi parkir maksimal untuk sepeda motor 798 kendaraan, sedangkan mobil 289 kendaraan, volume parkir sepeda motor 2550 kendaraan/hari dan 644 mobil kendaraan/hari, durasi parkir sepeda motor rata-rata 1,56 jam sedangkan mobil 2,57 jam, tingkat pergantian parkir untuk sepeda motor 3,38 kend./Petak sedangkan mobil 3,38 kend./Petak, Indeks parkir maksimal untuk sepeda motor 105,70\%, terjadi pada jam 10.30 - 10.45 WIB dan mobil sebesar 152.11\% terjadi pada jam 15.45 - 16.00 WIB. Pengendara yang menggunakan lahan parkir kurang dari 5 menit atau untuk mengantar sebanyak 260 kendaraan. Untuk itu ruang parkir Kantor
\end{abstract}


Balaikota Surakarta walaupun jumlah SRP yang tersedia lebih besar akumulasi parkirnya, Realita di lapangan ruang parkir relatif cukup, karena masih banyak kendaraan yang masuk untuk mengantar (tidak melakukan parkir). Sehingga di rekomendasikan pengaturan parkirnya dengan penambahan petugas yang mengawasi parkiran sehingga parkiran tertata dengan rapi tanpa adanya kendaraan parkir sembarangan yang dapat menghambat sirkulasi kendaraan lain, terutama pada parkir sepeda motor.

Kata kunci :Satuan Ruang Parkir (SRP), Perkantoran, Inventarisasi Parkir, Kebutuhan Ruang Parkir

\section{PENDAHULUAN}

Balaikokta merupakan bangunan administratif utama bagi pemerintahan kota dan tempat pusat para dewan kota, departemen terkait dan para pegawai pemerintah kota. Di sinilah, walikota menjalankan fungsinya. Berdasarkan data sekunder yang diperoleh dari website Badan Pusat Statistik Kota Surakarta, jumlah pegawai negeri sipil yang masih aktif bekerja di kota Surakarta adalah sebesar 9.147 orang. Dari jumlah tersebut, jumlah pegawai yang berkantor dikompleks Balaikota Surakarta sebesar 3.229 orang.Balaikota juga tidak terlepas dari masalah perparkiran yang dapat mengganggu tingkat kenyamanan dalam proses pelayanan yang diberikan oleh pihak balaikota.

Meningkatnya jumlah kendaraan mobil atau sepeda motor seharusnya diimbangi oleh peningkatan ketersediaan parkir yang baik, namun keterbatasan ruang tidak memungkinkan untuk perluasan tempat parkir sehingga banyak pengunjung Kantor Balaikota Surakarta yang parkir di badan jalan(on street parking). Kegiatan perparkiran pada badan jalan di sekitar Balaikota Surakarta dapat mengurangi kapasitas di Jalan Ronggowasito tersebut dan akhirnya mengurangi kelancaran lalulintas.

Mengatasi hal tersebut, survai inventarisasi parkir merupakan salah satu solusi alternatif untuk mengetahui fasilitas ruang parkir yang tersedia di Kantor Balaikota Surakarta.Meskipun demikian beberapa perancangan atau desain fasilitas parkir dapat dipilih dengan melihat lahan yang ada. Manajemen parkir yang baik harus mempertimbangkan keamanan, kenyamanan, dan efisiensi bagi pengguna parkir. Untuk itu dari penelitian ini diharapkan dapat menganalisis dan mengetahui karakteristik kebutuhan parkir mobil dan motor di areal parkir Kantor Balaikota Surakarta pada kondisi eksisting lalu memberi solusi pemecahan masalah parkir untuk meningkatkan kualitas parkir di areal parkir tersebut.

Penelitian tentang evaluasi fasilias parkir sebelumnya telah dilakukan oleh Karnawan Joko setyono (2010), Putu Alit Suthanaya (2010), Lindawati MZ (2012), Ahmam Brika dkk, (2014), Prima Juanita dkk (2014), namun berbeda dengan penelitian Ibrahim Al-Bahadly dkk (2014) dan Sharaf A Alkheder,dkk (2017) yang menggunakan aplikasi atau perangkat lunak. Perbedaan dari penelitian sebelumnya adalah penelitian ini lebih berfokus pada karakteristik parkir dan tempat penelitian yang di lakukan di Kantor Balaikota Surakarta. Persamaan dengan Karnawan Joko setyono (2010), Alit Suthanaya (2010), Lindawati MZ (2012) pada moda yang akan di teliti namun dengan variabel dan metode yang berbeda.

\section{Pengertian Parkir}

Parkir adalah keadaan tidak bergerak dari suatu kendaraan yang bersifat sementara (Direktorat Jendral Perhubungan Darat, 1996, 1). Selain Pengertian di atas beberapa ahli memberikan definisinya tentang parkir, yaitu :

1. Semua kendaraan tidak mungkin bergerak terus, pada suatu saat ia harus berhenti untuk sementara waktu (menurunkan muatan) atau berhenti cukup lama yang disebut parkir (warpani,1992).

2. Jangka waktu parkir (parking duration) adalah lama parkir suatu kendaraan untuk satu ruang parkir (Edward,1992)

Berdasarkan dari definisi-definisi di atas maka dapat ditarik kesimpulan bahwa parkir adalah suatu keadaan tidak bergerak sutau kendaraan bermotor atau tidak bermotor yang dapat merupakan awal dari perjalanan dengan jangka waktu tertentu sesuai dengan keadaan dan kebutuhannya yang membutuhkan suatu areal sebagai tempat pemberhentian yang diselenggarakan baik oleh pemerintah maupun pihak lain yang dapat berupa perorangan maupun badan usaha

\section{Fasilitas Parkir}

Fasilitas parkir adalah lokasi yang ditentukan sebagai tempat pemberhentian kendaraan yang bersifat tidak sementara untuk melakukan kegiatan pada suatu kurun waktu.Fasilitas parkir bertujuan untuk memberikan tempat istirahat kendaraan dan menunjang kelancaraan arus lulu lintas (Departemen Perhubungan Darat, 1998). Pada kota-kota besar area parkir merupakan suatu kebutuhan bagi pemilik kendaraan. Dengan demikian perencanaan dalam menyelenggarakan fasilitas parkir adalah suatu metoda perencanaan dalam menyelenggarakan 
fasilitas parkir kendaraan, baik di badan jalan (on-street parking) maupun di luar badan jalan (off-street parking) (Departemen Perhubungan Darat, 1998).Pengadaan fasilitas parkir kendaaran dapat dikelompokkan sebagai berikut.

Fasilitas parkir di badan jalan

Pengadaan fasilitas parkir di badan jalan khususnya sistem perparkiran yang sesuai dengan pola pengaturan untuk masing-masing ruas jalan yang diperbolehkan untuk parkir dilaksanakan oleh DLLAJ (Dinas Lalu Lintas Angkatan Jalan).

Fasilitas parkir di luar badan jalan

Pengadaan fasilitas parkir di luar badan jalan baik yang berupa taman parkir maupun gedung parkir dapat dilakukan oleh :

a. Pemerintahan daerah.

b. Swasta.

c. Pemerintaan daerah bekerja sama dengan swasta.

Keberadaan fasilitas parkir untuk umum berupa gedung parkir atau taman parkir harus menunjang keselamatan dan kelancaran lalu lintas, sehingga penempatan lokasi parkir harus dirancang agar tidak mengganggu kelancaran arus lalu lintas (pedoman Perencanaan dan Pengoperasian Fasilitas Parkir, Direktorat Jendral Perhubungan Darat 1998).

\section{Karakteristik Parkir}

Karakteristik parkir dimaksudkan sebagian sifat-sifat dasar yang memberikan penilaian terhadap pelayanan parkir dan permasalahan parkir yang terjadi pada lokasi studi. Berdasarkan karakteristik parkir, akan dapat diketahui kondisi perparkiran yang terjadi pada lokasi studi seperti mencakup volume parkir, akumulasi parkir, durasi parkir, angka pergantian parkir, indeks parkir.

\section{Volume parkir}

Volume parkir adalah jumlah kendaraan yang menggunakan suatu lahan parkir tertentu dalam kurun waktu tertentu. Rumus yang digunakan untuk menghitung volume parkir adalah:

Volume $=\mathrm{Nin}+\mathrm{X}($ kendaraan $)$

Keterangan:

Nin = Jumlah kendaraan yang masuk(kendaraan).

$\mathrm{X}=$ Kendaraan yang sudah ada sebelum waktu survai (kendaraan).

\section{Akumulasi parkir}

Akumulasi parkir merupakan jumlah kendaraan yang parkir di suatu tempat pada waktu tertentu dan dapat dibagi sesuai dengan kategori jenis maksud perjalanan, dimana integrasi dari akumulasi parkir selama periode tertentu menunjukkan beban parkir (jumlah kendaraan parkir) dalam satuan jam kendaraan per periode waktu tertentu . Akumulasiparkir $=(\mathrm{Ei}-\mathrm{Ex}+\mathrm{x})$

Dengan :

$\mathrm{Ei}=$ Entry (kendaraan yang masuk kelokasi)

Ex $=$ Exit (kendaraan yang keluar lokasi)

$\mathrm{x}=$ kendaraan yang ada

\section{Indeks Parkir}

Indeks parkir adalah prosentase kendaraan yang menggunakan pelataran parkir dengan jumah areal parkir yang tersedia dalam periode waktu tertentu .

IP $=($ Akumulasi Parkir : Ruang Parkir Tersedia) X $100 \%$

\section{Tingkat Pergantian Parkir (Parking Turn Over)}

Tingkat pergantian parkir akan menunjukkan tingkat penggunaan ruang parkir yang diperoleh dengan cara membagi volume parkir dengan luas ruang parkir yang tersedia untuk periode waktu tertentu. Rumus yang digunakan untuk menghitung tingkat pergantian parkir adalah :

$P T O=($ volume parkir : Jumlah ruang parkir yang tersedia $)$

\section{Durasi Parkir}

Durasi parkir adalah lama waktu kendaraan parkir, diperoleh dari selisih waktu kendaraan keluar dan kendaraan masuk. Lamanya parkir dinyatakan dalam jam. Rumus yang digunakan untuk menghitung rata-rata lamanya parkir adalah :

Durasi $=$ Ex time - En time

Keterangan: 
Ex time $=$ waktu kendaraan pergi

En time = waktu kendaraan datang

\section{METODE PENELITIAN}

Penelitian dilakukan di kawasan kantor Balaikota Surakarta

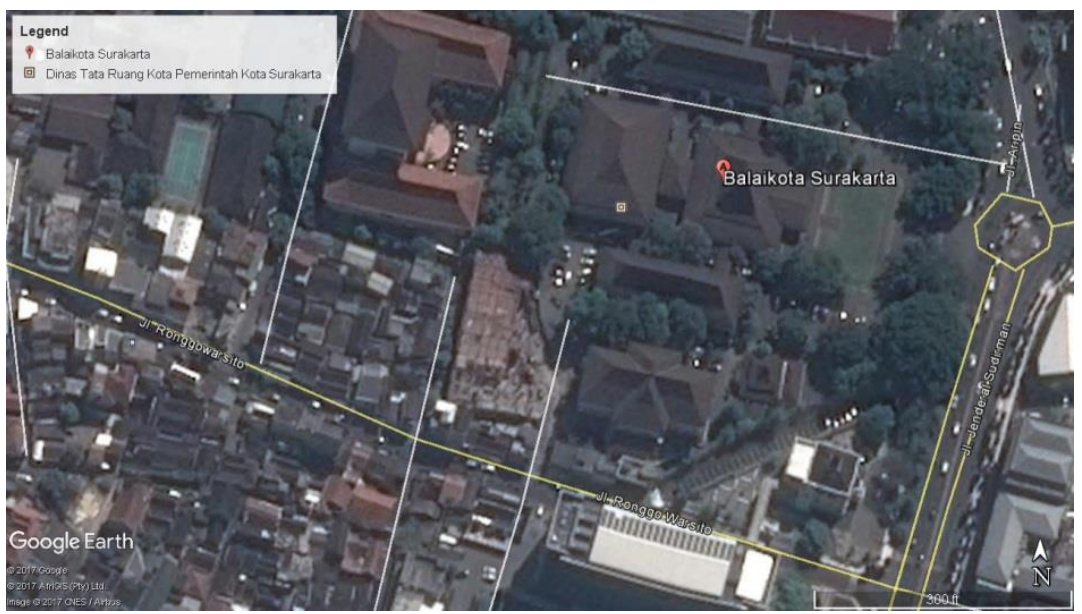

\section{Gambar 1. Lokasi Penelitian}

(Sumber: google maps, 2017)

Data primer didapat dengan melakukan survei secara langsung pen catatan nomor plat kendaraan yang masuk dan keluar dilakukan selama waktu operasional Kantor Balaikota Surakarta dan survei kebutuhan ruang parkir. Data sekunder berupa peta yang memperlihatkan data luas bangunan parkir di Kantor Balaikota Surakarta. metode survai dilakukan dengan metode inventarisasi ruang parkir dan kebutuhan ruang parkir.sistem pengambilan data parkir menggunakan survai kordon dan survai patrol. Survai kordon dilakukan untuk pengambilan data di dalam lokasi Balaikota Surakarta sedangakan survai patrol dilakukan untuk pengambilan data di Jalan ronggowarsito.

\section{HASIL DAN PEMBAHASAN}

\section{A. Lokasi Dalam Balaikota Surakarta}

\section{Akumulasi parkir}

Tabel 1 menjelaskan akumulasi parkir pada Kantor Balaikota Surakarta.Akumulasi tertinggi di lokasi studi pada Hari Rabu untuk kendaraan sepeda motor adalah 798 kendaraan, terjadi pada jam 10.30 WIB - 10.45 WIB. Kendaraan mobil adalah 289 kendaraan, terjadi pada jam 15.45 WIB - 16.00 WIB, Akumulasi tertinggi pada Hari Kamis di areal parkir Kantor Balaikota Surakarta, untuk sepeda motor yaitu sebesar 604 kendaraan pada jam 11.00 WIB - 11.15 WIB dan untuk mobil yaitu sebesar 140 kendaraan pada jam 14.30 WIB - 14.45 WIB. Berdasarkan jumlah akumulasi kendaraan menujukkan bahwa akumulasi terbesar pada kendaraan sepeda motor terjadi pada Hari Rabu, sedangkan pada Hari Kamis mengalami penurunan akumulasi yaitu mobil dan sepeda motor.

Tabel 1 Akumulasi Parkir

\begin{tabular}{cccccc}
\hline Hari & Jenis kendaraan & waktu & $\begin{array}{c}\text { Jumlah } \\
\text { kendaran } \\
\text { masuk }\end{array}$ & $\begin{array}{c}\text { Jumlah } \\
\text { kendaraan } \\
\text { keluar }\end{array}$ & $\begin{array}{c}\text { Akumulasi } \\
\text { Parkir Puncak } \\
\text { (15 menit })\end{array}$ \\
\hline Rabu, & Mobil & $10.30-$ & 68 & 61 & 289 \\
& & 10.45 & & & \\
\cline { 2 - 6 } & Sepeda motor & $15.45-$ & 4 & 2 & \\
\hline Kamis, & & 16.00 & & & 140 \\
$28 / 9 / 2017$ & Mobil & $14.45-$ & 12 & 12 & \\
\hline
\end{tabular}




$\begin{array}{lllll}\text { Sepeda motor } & 11.15- & 76 & 70 & 610\end{array}$

\section{Volume Parkir}

Table 2 menjelaskan volume parkir pada lokasi studi. Hasil pengamatan pada penelitian ini menunjukkan bahwa volume terbesar yang masuk areal parkir Kantor Balaikota Surakarta , untuk kendaraan sepeda motor terjadi pada Hari Rabu yaitu 2550 kendaraan. Perbedaan volume kendaraan sepeda motor yang masuk pada hari Rabu dan Kamis adalah 318 kendaraan. Untuk volume terbesar kendaraan mobil terjadi pada Hari Rabu yaitu 644 kendaraan. Perbedaan volume kendaraan mobil yang masuk pada Hari rabu dengan hari kamis lebih sedikit dibandingkan dengan sepeda motor yaitu mengalami penurunan sebesar 30 kendaraan.

Tabel 2 Volume parkir

\begin{tabular}{ccc}
\hline Jenis Kendaraan & Hari & $\begin{array}{c}\text { Volume } \\
\text { (Kendaraan) }\end{array}$ \\
\hline Sepeda Motor & Rabu & 2550 \\
\cline { 2 - 3 } & Kamis & 2232 \\
\hline Mobil & Rabu & 644 \\
\cline { 2 - 3 } & Kamis & 614 \\
\hline
\end{tabular}

\section{Durasi parkir}

Dari data hasil survai yang telah dilakukan maka dapat diketahui bahwa nilai durasi parkir tertinggi sepeda motor terjadi pada hari Kamis menit ke 30-60 sebanyak 418 kendaraan dan pada Hari Rabu pada menit ke 0-30 sebanyak 501 kendaraan, sedangkan durasi parkir tertinggi mobil terjadi pada Hari Kamis menit ke 0-30 sebanyak 180 kendaraan dan pada hari rabu menit ke 0-30 sebanyak 104 kendaraan. Sedangkan durasi parkir rata-rata terbesar sepeda motor pada Hari Kamis sebesar 126,47 menit dan durasi parkir rata-rata terbesar mobil pada Hari Rabu sebesar 177,47 menit.

Tabel 3 Durasi rata-rata parkir

\begin{tabular}{|c|c|c|c|}
\hline \multicolumn{2}{|c|}{ Hari / Tanggal } & \multicolumn{2}{|c|}{ Durasi Rata - Rata } \\
\hline & & (jam:Menit:Detik) & menit \\
\hline \multirow{2}{*}{$\begin{array}{c}\text { Rabu, } \\
27 / 9 / 2017\end{array}$} & Motor & $1: 56: 27$ & 116,27 \\
\hline & Mobil & $2: 57: 14$ & 177,14 \\
\hline \multirow{2}{*}{$\begin{array}{c}\text { Kamis, } \\
28 / 9 / 2017\end{array}$} & Motor & $2: 06: 47$ & 126,47 \\
\hline & Mobil & $2: 46: 47$ & 166,47 \\
\hline
\end{tabular}

\section{Pergantian Parkir (Parking turnover)}

Tingkat pergantian parkir diperlihatkan pada table 4. Tingkat pergantian parkir tertinggi pada Hari Rabu untuk jenis kendaran sepeda motor sebesar 3,38 kend./Petak sedangkan mobil 3,38 kend./Petak dan pergantian parkir tertinggi pada Hari Kamis untuk jenis kendaraan sepeda motor sebesar 2,96 kend./Petak sedangkan mobil 3,23 kend./Petak.

Tabel 4 Tingkat Pergantian Parkir (Parking turnover)

\begin{tabular}{ccccc}
\hline $\begin{array}{c}\text { Hari } / \\
\text { tanggal }\end{array}$ & $\begin{array}{c}\text { Jenis } \\
\text { kendaraan }\end{array}$ & Volume & $\begin{array}{c}\text { Jumlah } \\
\text { Petak }\end{array}$ & Turn Over \\
\hline $\begin{array}{c}\text { Rabu, } \\
27 / 9 / 2017\end{array}$ & $\begin{array}{c}\text { Sepeda } \\
\text { Motor }\end{array}$ & 2550 & 755 & 3,38 \\
\hline $\begin{array}{c}\text { Rabu, } \\
27 / 9 / 2017\end{array}$ & Mobil & 644 & 190 & 3,38 \\
\hline $\begin{array}{c}\text { Kamis, } \\
28 / 9 / 2017\end{array}$ & $\begin{array}{c}\text { Sepeda } \\
\text { Motor }\end{array}$ & 2232 & 755 & 2,96 \\
\hline $\begin{array}{c}\text { Kamis, } \\
28 / 9 / 2017\end{array}$ & Mobil & 614 & 190 & 3,23 \\
\hline
\end{tabular}

\section{Indeks Parkir}


Tabel 5 memperlihatkan nilai Indeks parkir. Dapat diketahui indeks tertinggi areal parkir Kantor Balaikota Surakarta, pada hari rabu untuk sepeda motor sebesar 105,70\%, terjadi pada jam 10.30 - 10.45 WIB sedangkan jenis kendaraan mobil sebesar $152.11 \%$, terjadi pada jam $15.45-16.00$ WIB. Sedangkan nilai indek terendah terjadi pada Hari Kamis sebesar 80,79\% untuk jenis kendaraan sepeda motor, terjadi pada jam 11.15 - 11.30 WIB dan $74,21 \%$ untuk jenis kendaraan mobil terjadi pada jam 10.30 - 10.45 WIB.

\section{Tabel 5 nilai Indeks Parkir}

\begin{tabular}{cccc}
\hline Hari / tanggal & $\begin{array}{c}\text { Jenis } \\
\text { kendaraan }\end{array}$ & $\begin{array}{c}\text { Indeks } \\
\text { Parkir }(\%)\end{array}$ & Waktu Tertinggi \\
\hline Rabu, & Sepeda & $105,70 \%$ & $10.30-10.45$ WIB \\
$27 / 9 / 2017$ & Motor & & \\
\hline Rabu, & Mobil & $152.11 \%$ & $15.45-16.00$ WIB \\
$27 / 9 / 2017$ & & & \\
\hline Kamis, & Sepeda & $80,79 \%$ & $11.15-11.30$ WIB \\
$28 / 9 / 2017$ & Motor & & \\
\hline Kamis, & Mobil & $74,21 \%$ & $10.30-10.45$ WIB. \\
$28 / 9 / 2017$ & & & \\
\hline
\end{tabular}

\section{B. Lokasi Luar Balaikota Surakarta}

\section{Akumulasi parkir}

Akumulasi tertinggi pada Hari Rabu di areal parkir Jalan Ronggowarsito, untuk mobil yaitu sebesar 5 kendaraan pada jam 12.45 WIB - 13.00 WIB dan untuk Hari Kamis sebesar 3 kendaraan. Berdasarkan jumlah akumulasi kendaraan menujukkan bahwa akumulasi terbesar terjadi pada Hari Kamis, sedangkan pada hari Rabu mengalami penurunan akumulasi.

Gambar 2 Akumulasi areal parkir mobil pada hari Rabu dan Kamis

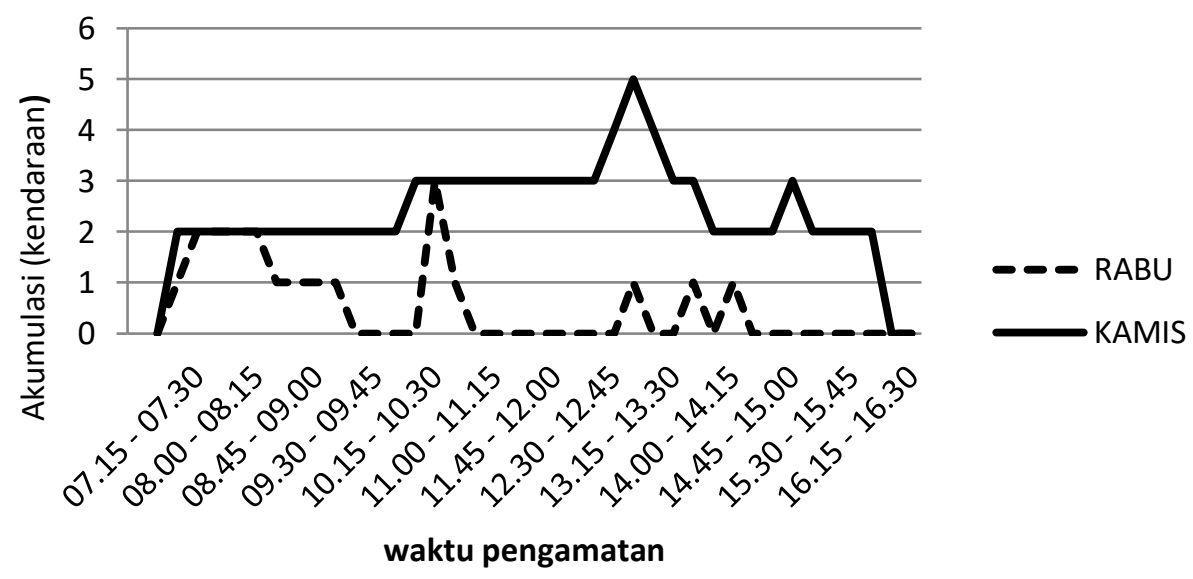

\section{Volume parkir}

Hasil pengamatan pada penelitian ini menunjukkan bahwa volume terbesar yang parkir di areal Jalan ronggowarsito, pada Hari Rabu yaitu 8 kendaraan dan pada Hari Kamis yaitu 7 kendaraan.Perbedaan volume kendaraan pada hari Rabu dan Kamis adalah 1 kendaraan.

Tabel 6 Volume Parkir Mobil Jalan Ronggowarsito

\begin{tabular}{ccc}
\hline $\begin{array}{c}\text { Jenis } \\
\text { Kendaraan }\end{array}$ & Hari & $\begin{array}{c}\text { Volume } \\
\text { (Kendaraan) }\end{array}$ \\
\hline Mobil & Rabu & 8 \\
& Kamis & 7 \\
\hline
\end{tabular}

\section{Durasi Parkir}

Pada tabel 7 menjelaskan nilai durasi parkir tertinggi mobil terjadi pada Hari Rabu menit $0-15$ sebanyak 5 kendaraan. Sedangkan durasi parkir rata-rata terbesar mobil pada Hari Kamis sebesar 195 menit dan durasi parkir rata-rata terbesar mobil pada Hari Rabu sebesar 39,22 menit. 


\begin{tabular}{|c|c|c|c|}
\hline \multirow{2}{*}{\multicolumn{2}{|c|}{ Hari / Tanggal }} & \multicolumn{2}{|c|}{ Durasi Rata - Rata } \\
\hline & & (Jam:Menit:Detik) & Menit \\
\hline $\begin{array}{c}\text { Rabu, } \\
27 / 9 / 2017\end{array}$ & Mobil & $0: 39: 22$ & 39,22 \\
\hline $\begin{array}{c}\text { Kamis, } \\
28 / 9 / 2017\end{array}$ & Mobil & $3: 15: 00$ & 195 \\
\hline
\end{tabular}

\section{Pergantian Parkir (Parking Turnover)}

Tingkat pergantian parkir diperlihatkan pada table 8 tingkat pergantian parkir tertinggi pada Hari Rabu untuk jenis kendaran mobil sebesar 1,14 kend./Petak dan pergantian parkir pada Hari Kamis terjadi penurunan yaitu sebesar 1 kend./Petak.

Tabel 8 Rekapitulasi hasil perhitungan Parking Turnover

\begin{tabular}{ccccc}
\hline $\begin{array}{c}\text { Hari } / \\
\text { tanggal }\end{array}$ & $\begin{array}{c}\text { Jenis } \\
\text { kendaraan }\end{array}$ & Volume & $\begin{array}{c}\text { Jumlah } \\
\text { Petak }\end{array}$ & $\begin{array}{c}\text { Turn } \\
\text { Over }\end{array}$ \\
\hline $\begin{array}{c}\text { Rabu, } \\
\text { 27/9/2017 }\end{array}$ & Mobil & 8 & 7 & 1,14 \\
\hline $\begin{array}{c}\text { Kamis, } \\
\text { 28/9/2017 }\end{array}$ & Mobil & 7 & 7 & 1 \\
\hline
\end{tabular}

\section{Indeks Parkir}

Table 9 memperlihatkan Indeks parkir tertinggi areal parkir Jalan Ronggowarsito, pada Hari Rabu untuk Mobil sebesar 42,86\%, terjadi pada jam 10.15 - 10.30 WIB, sedangakan untuk Hari Kamis sebesar $71.43 \%$, terjadi pada jam 12.45 - 13.00 WIB.

Tabel 9 Rekapitulasi Hasil Perhitungan Indeks Parkir

\begin{tabular}{|c|c|c|c|}
\hline $\begin{array}{l}\text { Hari / } \\
\text { tanggal }\end{array}$ & $\begin{array}{l}\text { Jenis } \\
\text { kendaraan }\end{array}$ & $\begin{array}{l}\text { Indeks } \\
\text { Parkir (\%) }\end{array}$ & Waktu Tertinggi \\
\hline $\begin{array}{l}\text { Rabu, } \\
27 / 9 / 2017\end{array}$ & Mobil & $42,86 \%$ & $\begin{array}{l}10.15-10.30 \\
\text { WIB }\end{array}$ \\
\hline $\begin{array}{l}\text { Kamis, } 28 \\
28 / 9 / 2017\end{array}$ & Mobil & $71.43 \%$ & $\begin{array}{l}12.45-13.00 \\
\text { WIB. }\end{array}$ \\
\hline
\end{tabular}

\section{PEMBAHASAN}

Dari data yang telah di survei inventarisasi parkir area Balaikota Surakarta untuk ruang parkir sepeda motor adalah 755 SRP dan mobil 190 SRP. Kebutuhan parkir dalam penelitian ini untuk hari Rabu sebesar 289 SRP mobil dan 798 SRP untuk sepeda motor, sedangkan untuk Hari Kamis sebesar 610 SRP mobil dan 140 SRP sepeda motor. Selisih antara data inventariasi parkir area Balaikota Surakarta dengan kebutuhan parkir dalam penelitian ini pada Hari Rabu adalah sebesar 99 SRP mobil dan 43 SRP untuk sepeda motor, sedangkan di Hari Kamis sebesar 145 SRP sepeda motor dan 50 SRP mobil.

Dari data tersebut sebenarnya Satuan Ruang Parkir (SRP) di kawasan Balaikota Surakarta relatif masih cukup untuk menampung kendaraan yang ada pada hari rabu, sedangkan untuk hari kamis cukup untuk menampung kendaraan yang parkir. Oleh karena itu banyak pengendara mobil yang parkir kurang dari 15 menit sangat tinggi dan tidak mendapatkan parkir di dalam kantor Balaikota sehingga menggunakan parkir di luar Balaikota Surakarta. Pengendara yang menggunakan lahan parkir kurang dari 5 menit atau untuk mengantar sebanyak 260 kendaraan. Hal ini mempengaruhi akumulasi parkir yang terjadi di kantor Balaikota Surakarta. Dari analisis tersebut Hari Kamis ideal kurang dari 100\%, hal ini dikarenakan ada beberapa data yang tidak tercatat waktu keluarnya, pada saat kompilasi. Pada hari rabu terjadi kehilangan data 16\% untuk sepeda motor dan 20\% untuk mobil (dari data survei 2400 kendaraan sepeda motor dan 563 kendaraan mobil, terdata 2020 kendaran sepeda motor dan 447 kendaraan mobil). Hari kamis terjadi kehilangan 10\% kendaraan sepeda motor dan $7 \%$ kendaraan mobil ( dari data survey 2342 kendaraan sepeda motor dan 620 kendaraan mobil, terdata 2114 kendaraan sepeda motor dan 587 kendaraan mobil). Hal ini di sebabkan karena pengumpulan data dicatat secara manual, sehingga terjadi kesalahan pada saat pencatatnya.Sehingga tidak ditemukan data masuk dan keluarnya.Untuk itu disarankan pengambilan data sebaiknya menggunakan video karena untuk mengurangi kesalahan pencatatan data. 
Dari penelitian sebelumnya yang telah di lakukan oleh Putu Alit Suthanaya (2010) yang di lakukan di pusat perbelanjaan di kabupaten badung dan Ahmam Birka, dkk (2014) yang di lakukan di stasiun kota baru malang, penelitian tersebut terjadi lonjakan pengguna parkir pada jam sibuk yang mengakibatkan tingginya akumulasi parkir dan indeks parkir yang lebih dari 1, hal ini menunjukan bahwa pada kondisi tersebut akumulasi parkir melebihi kapasitas parkir yang ada, menyebabkan banyak kendaraan yang tidak mendapat parkir pada petak yang di sediakan dan menjadi hal biasa bila disuatu perkantoran atau fasilitas umum yang banyak pengunjungnya tidak mendapatkan tempat parkir pada jam sibuk. Dari penelitian yang telah di lakukan di Kantor Balaikota Surakarta lonjakan pengunjung pengguna parkir juga terjadi pada jam sibuk yang mengakibatkan tingginya akumulasi parkir dan indeks parkir yang lebih dari 1 yang menyebabkan akumulasi parkir melebihi kapasitas yang ada.

\section{SIMPULAN}

Dari hasil analisis yang telah dilakukan dapat disimpulkan bahwa:

1. Ketersediaan Satuan Ruang Parkir (SRP) yang tersedia di Kantor Balaikota Surakarta sebanyak 755 SRP untuk sepeda motor dan 190 SRP untuk mobil.

2. Karakteristik parkir yang diperoleh adalah sebagai berikut:

Aktifitas terpadat terjadi pada hari Rabu 27 September 2017, maka karakteristik parkirnya dapat dinyatakan sebagai berikut: akumulasi parkir maksimal untuk sepeda motor 798 kendaraan, sedangkan mobil 289 kendaraan, volume parkir sepeda motor 2550 kendaraan/hari dan 644mobil kendaraan/hari, durasi parkir sedepa motor rata-rata 2,57 jam sedangankan mobil 1,56 jam, tingkat pergantian parkir untuk sepeda motor 3,38 kend./Petak sedangkan mobil 3,38 kend./Petak, Indeks parkir maksimal untuk sepeda motor 105,70\%, terjadi pada jam 10.30 - 10.45 WIB dan mobil sebesar 152.11\% terjadi pada jam 15.45 - 16.00 WIB.

3. Ruang parkir Kantor Balaikota Surakarta walaupun jumlah SRP yang tersedia lebih besar akumulasi parkirnya, realita di lapangan ruang parkir relatif cukup karena masih banyak kendaraan yang masuk untuk mengantar (tidak melakukan parkir) sehingga di rekomendasikan pengaturan parkirnya dengan penambahan petugas yang mengawasi parkiran sehingga parkiran tertata dengan rapi tanpa adanya kendaraan parkir sembarangan yang dapat menghambat sirkulasi kendaraan lain, terutama pada parkir sepeda motor. Dalam indentifikasi menajemen keamanan parkir ternyata setelah jam 3 sore tidak ada petugas parkir maka untuk keamanan parkir sebaiknya pemberian karcis ditutup setelah jam 5 sore karena ada sebagian pengunjung yang datang hinggal jam 5 sore.

\section{SARAN}

Setelah melakukan analisa dalam penelitian ini dan telah mendapatkan beberapa kesimpulan di atas, maka saran yang dapat disampaikan adalah sebagai berikut :

1. Dalam pengambilan data di Kantor Balaikota Surakarta dalam penelitian ini masih menggunakan cara manual, sebaiknya pengambilan data menggunakan video karena untuk mengurangi kesalahan pencatatan data dan lebih akurat.

2. Adanya kebijakan dari Balaikota Surakarta untuk pengurangan pemakaian kendaraan pribadi terutama bagi pegawai Kantor Balaikota Surakarta guna untuk meningkatkan ketersediaan ruang parkir bagi masyarakat yang berkepentingan di Kantor Balaikota Surakarta akibat banyaknya aktivitas dari kendaraan pribadi, sehingga akan tercipta penataan parkir yang lebih rapi, aman, nyaman dan teratur.

\section{DAFTAR PUSTAKA}

Ahmam Birka, dkk, 2014, "Evaluasi fasilitas parkir di stasiun kota Baru Malang" Fakultas Teknik, Universitas Brawijaya. Malang.

Ibrahim Al-Bahadly, dkk, 2014, “Intelligent Parking Management System Based on Image Processing”. Massey University, New Zealand.

Karnawan Setyono, 2010, "Evaluasi kebutuhan ruang parkir di kampus universitas Brawijaya", Fakultas Teknik, Universitas Brawijaya. Malang.

Lindawati MZ, 2012, “Analisis Kebutuhan dan Penataan Ruang Parkir di Kampus Universitas Baturaja”. Fakultas Teknik, Universitas Baturaja, Batu raja.

Putu Alit Suthanaya, 2010, "Analisis karakteristik dan kebutuban ruang parkir pada pusat perbelanjaan di Kabupaten Badung" Fakultas Teknik, Universitas Udayana, Denpasar.

Pedoman Perencanaan dan Pengoperasian Fasilitas Parkir, Direktorat Jenderal Perhubungan Darat 1998

Prima Juanita, dkk, 2017, "Karakteristik dan kebutuban parkir mobil di kampus terpadu universitas islam Indonesia". Fakultas Teknik. Jurusan Teknik Sipil Universitas Islam Indonesia.Yogyakarta.

Sharaf A. Alkheder, dkk, 2017, "Parking problems in Abu Dhabi, U AE toward an intelligent parking management system "ADIP : Abu Dhabi Intelligent Parking". Massey University. New Zealand. 